\title{
Verloove Vanhorick-Brubakk syndrome
}

INSERM

\section{Source}

INSERM. (1999). Orphanet: an online rare disease and orphan drug data base. Verloove Vanhorick-Brubakk syndrome. ORPHA:3429

Verloove Vanhorick-Brubakk syndrome is a multiple congenital anomalies/dysmorphic syndrome characterized by multiple skeletal malformations (short femora and humeri, bilateral absence of metatarsal and metacarpal bone in hands and feet, bilateral partial syndactyly of fingers and toes or oligopolysyndactyly, deformed lumbosacral spine), congenital heart disease (truncus arteriosus), lung and urogenital malformations (bilateral bilobar lungs, horseshoe kidney, cryptorchidism), and facial malformations (bilateral cleft lip and palate, micrognathia, small, low-set ears without external meatus). It is lethal in the neonatal period. There have been no further descriptions in the literature since 1981. 